\title{
Kepastian Hukum mengenai Penjamin Simpanan bagi Nasabah pada Lembaga Perkreditan Desa di Bali
}

\author{
Dewa Putu Adnyana1, I Ketut Sudantra²
}

${ }^{1}$ Kantor Hukum Dewa Putu Adnyana,S.H \& Rekan, E-mail: dewaputuadnyana@gmail.com

${ }^{2}$ Fakultas Hukum Universitas Udayana, E-mail: ketut_sudantra@unud.ac.id

\begin{tabular}{l}
\hline Info Artikel \\
\hline Masuk: 14 Juli 2020 \\
Diterima: 28 Desember 2020 \\
Terbit: 31 Desember 2020 \\
Keywords: \\
Legal Certainty; Deposit \\
Guarantor; Legal Pluralism \\
\\
\\
DOI: \\
p14 \\
Cimpanan; Pluralisme Hukum \\
Corresponding Author: \\
Dewa Putu Adnyana, Email: \\
dewaputuadnyana@gmail.com \\
Kata kunci: \\
\end{tabular}

\begin{abstract}
The regulation of legal protection for customers who have savings funds in village financial institutions (LPD) is unclear. This causes no legal certainty for customers if the LPD experiences financial problems. The existence of LPDs in Bali is regulated in two types of legal rules, namely state law and customary law (legal pluralism). Analyzing the legal certainty aspects of deposit guarantor in statutory regulations and customary law is the aim of this research. This study uses a normative legal research methodology. This study uses two types of approaches namely, the statute and the conceptual approaches. The legal materials chosen as the basic analysis are primary and secondary legal materials. The conclusion of this study shows that the role of state law is more dominant than customary law. The above conclusion is shown by the fact of the research that most of the matters related to the technical operations of the LPD are regulated by the state law, in this case, is regional regulation about LPD. Based on the results of the study on the norms of local regulations on LPD and the nine awig -awig as a form of customary law from representatives of the nine regencies and city in Bali, there is no regulation on deposit guarantor institutions for LPD customers in Bali to provide legal protection. So that, regulating LPDs in Bali with two legal systems, namely the state law and the customary law system, does not guarantee legal certainty for the safety of customer's deposits.
\end{abstract}

\section{Abstrak}

Pengaturan perlindungan hukum bagi nasabah yang mempunyai dana simpanan di Lembaga Perkreditan Desa (LPD) saat ini tidak jelas. Hal ini menyebabkan tidak ada kepastian hukum bagi nasabah apabila LPD mengalami masalah keuangan. Keberadaan LPD di Bali diatur dalam dua jenis aturan hukum yaitu hukum negara dan hukum adat (pluralisme hukum). Mengkaji aspek kepastian hukum penjamin simpanan dalam setiap norma dalam peraturan perundang-undangan serta dalam hukum adat merupakan tujuan penelitian ini. Penelitian ini menggunakan metode penelitian hukum doktrinal (normatif). Penelitian ini menggunakan dua jenis pendekatan yaitu pendekatan peraturan perundang-undangan (statute approach), dan pendekatan konsep (conceptual approach). Adapun bahan hukum yang dipilih sebagai dasar analisis adalah bahan hukum primer dan bahan hukum sekunder. Kemudian kesimpulan dari penelitian ini menyebutkan bahwa dua sistem hukum dalam pengaturan LPD 
di Bali menunjukkan peran hukum negara lebih dominan daripada hukum adat. Kesimpulan ini ditunjukkan oleh fakta penelitian yang ditemukan bahwa sebagian besar hal yang berkaitan dengan teknis operasional LPD yang merupakan satusatunya organisasi keuangan milik Desa Adat di Bali diatur oleh hukum negara dalam hal ini diatur dalam peraturan daerah tentang LPD. Kemudian, berdasarkan hasil kajian terhadap norma peraturan daerah tentang LPD dan terhadap sembilan awig-awig sebagai bentuk hukum adat dari perwakilan Kabupaten dan Kota di Bali, tidak ada ditemukan pengaturan tentang lembaga penjamin simpanan bagi nasabah LPD di Bali untuk memberikan perlindungan hukum. Dengan demikian pengaturan LPD di Bali dengan dua sistem hukum yaitu hukum negara dan sistem hukum adat ternyata tidak menjamin kepastian hukum bagi keamanan dana simpanan para nasabah.

\section{Pendahuluan}

Ada persoalan krusial dibalik keberadaan Lembaga Perkreditan Desa (selanjutnya disebut LPD). Keberadaan LPD telah diakui berperan besar dalam meningkatkan kesejahteraan masyarakat Bali, terutama bagi masyarakat hukum adatnya, baik sebagai individu anggota masyarakat adat (krama desa adat), maupun sebagai masyarakat sebagai kesatuan (Desa Adat). Persoalan tersebut adalah berkaitan dengan perlindungan hukum terhadap dana nasabah yang disimpan di LPD, baik berupa tabungan maupun simpanan berjangka (deposito). Adanya kepastian hukum sebagai penjamin simpanan merupakan sebuah jawaban bagi perlindungan hukum dan keamanan dana yang disimpan para nasabah LPD.

Persoalan tentang perlindungan hukum terhadap dana simpanan di LPD sudah pernah dikaji oleh beberapa penulis sebelumnya, tetapi belum mengungkap secara jelas aspek kepastian hukum berkaitan penjamin simpanan dana para nasabah di LPD, apabila sewaktu-waktu LPD di Bali mengalami masalah keuangan, sehingga nasib para penyimpan dana menjadi mengambang. Penelitian yang berjudul Keberadaan LPD Di Bali Dalam Perspektif Undang-Undang Nomor 1 Tahun 2013 Tentang Lembaga Keuangan Mikro, selanjutnya akan disebut dengan UU LKM, sudah mempertanyakan bagaimana perlindungan hukum pengguna jasa (nasabah) LPD apabila LPD tidak mampu memenuhi kewajiban mengembalikan dana nasabah, tetapi para penulis tidak memberikan jawaban yang memuaskan mengenai subyek hukum yang dapat memberikan perlindungan terhadap jaminan keamanan dana nasabah. Dalam kesimpulannya, penulis hanya menegaskan bahwa pasca terbitnya UU LKM, tidak ada perlindungan hukum bagi pengguna jasa LPD karena ketentuan-ketentuan perlindungan hukum yang diatur oleh Undang Nomor 1 Tahun 2013 tidak berlaku terhadap LPD. ${ }^{1}$ Penulis lain, Yasa, Rudi \& Kusuma, juga meneliti aspek perlindungan hukum terhadap dana simpanan para nasabah LPD di Bali, tetapi para penulis ini juga tidak mengungkap aspek kepastian hukum bagi dana simpanan nasabah di LPD. Para penulis lebih menekankan pada upaya-upaya yang dapat ditempuh oleh nasabah untuk mendapatkan kembali dananya. Dalam kesimpulan tulisannya, para penulis

\footnotetext{
1 Putra, A. K. Y., \& Sarjana, I. M. Keberadaan Lembaga Perkreditan Desa Di Bali Dalam Perspektif Undang-Undang Nomor 1 Tahun 2013 Tentang Lembaga Keuangan Mikro. Kertha Semaya: Journal Ilmu Hukum, 6(6), 1-13. h. 5, 12.
} 
menunjukkan dua upaya yang dapat dilakukan oleh nasabah, yaitu mediasi dan/atau menggugat ke Pengadilan².

Keberadaan LPD sebagai sebuah lembaga keuangan masyarakat hukum adat di Bali, sudah mengalami perjalanan sejarah yang cukup panjang. LPD di Bali awalnya dibentuk pada masa pemerintahan Ida Bagus Mantra (alm), yang bertujuan supaya Desa Adat di Bali memiliki sebuah usaha mandiri yang dapat menopang kebutuhan hidup dan kehidupannya, keberlangsungan budaya dan adatnya yang diilhami oleh ajaran agama. Seperti contoh untuk menopang biaya membangun dan memperbaiki Pura serta biaya ritualnya. Sebagai proyek percontohan, melalui Kep. Gub Bali No : 1A Tahun 1985, tertanggal 2 Januari 1985 dibentuklah pertama kali delapan unit LPD yang tersebar di setiap kabupaten di provinsi Bali antara lain, LPD Lukluk (Badung), LPD Buahan (Tabanan), LPD Ekasari (Jembrana), LPD Julah (Buleleng), LPD Selulung (Karangasem), LPD Kubu (Bangli, dan LPD Manukaya (Gianyar). ${ }^{3}$

Saat ini pembentukan dan pengelolaan LPD di Bali diatur oleh Peraturan Daerah Provinsi Bali Nomor 4 Tahun 2019 tentang Desa Adat yang selanjutnya akan disebut dengan Perda Desa Adat. Terminologi yang digunakan dalam Perda ini adalah Labda Pacingkreman Desa Adat (Pasal 1 angka 34). Berdasarkan ketentuan Pasal 61 ayat (2) Perda Desa Adat, diatur LPD diakui sebagai lembaga keuangan milik desa adat yang eksistensi, pembentukan dan pengelolaannya didasarkan pada hukum adat, tetapi mengenai pengaturan mengenai panduan, tata cara pendirian LPD ditentukan lebih lanjut dalam Peraturan Daerah lain. Karena belum ada Perda lain yang dibentuk setelah berlakunya Perda Desa Adat, maka saat ini yang berlaku adalah Peraturan Daerah Provinsi Bali Nomor 3 tahun 2017 Tentang LPD yang selanjutnya disebut dengan Perda LPD. Pasal 12 Perda LPD menentukan bahwa LPD dalam menjalankan aktifitasnya mengelola keuangan Desa Adat didasari oleh ketentuan yang ada dalam Awig-awig, Pararem Desa dan Peraturan Daerah tentang LPD. Secara normatif LPD selain diatur dalam Perda, keberadaan LPD di Bali juga diakui dalam UndangUndang, pengakuan tersebut berkaitan dengan keberadaan LPD didasarkan pada pakem-pakem hukum adat dalam ketentuan pasal 39 ayat (3) UU LKM . Semua uraian pasal dalam instrumen hukum negara (Perda Desa adat, Perda LPD dan UU LKM) ini menyebut bahwa operasional atau pengelolaan LPD juga diatur berdasarkan hukum adat. Model pengaturan lebih dari satu sistem hukum ini dalam studi ilmu hukum disebut dengan pluralisme hukum.

Memang tidak dapat dipungkiri peran LPD kini mendapatkan banyak pujian dari berbagai kalangan karena mampu menunjang perekonomian dan kesejahteraan warga Desa Adat. Hal ini dapat dibuktikan dengan penelitian dari Keberhasilan ini didukung oleh penelitian yang dilakukan oleh Murniasih yang menyimpulkan, LPD bermanfaat bagi pembangunan Desa Adat yang nantinya akan mampu meningkatkan kesejahteraan masyarakat desa di Bali ini akan berpengaruh terhadap kesejahteraan

2 Yasa, P. H., Rudy, D. G., \& Kusuma, A. G. A. D. Perlindungan Hukum Terhadap Dana Nasabah Yang Disimpan Pada Lembaga Perkreditan Desa (LPD). Kertha Semaya: Journal Ilmu Hukum. h. 5.

${ }^{3}$ Pramana, I. M. I. D., \& Lemes, I. N. (2019). Akibat Hukum Pemberian Kredit Kepada Krama Desa Lain Pada Lembaga Perkreditan Desa Pakraman Anturan, Kecamatan Buleleng, Kabupaten Buleleng. Kertha Widya, 5(1). DOI: https://doi.org/10.37637/kw.v5i1.276. h. 2. 
masyarakat Bali. ${ }^{4}$ Akan tetapi, ditengah pujian terhadap LPD ternyata tidak sedikit LPD yang telah mengalami masalah keuangan yang mengakibatkan LPD tidak mampu mengembalikan dana simpanan kepada para nasabahnya, seperti diungkapkan beberapa media online. Misalnya, beberapa nasabah LPD Grokgak (Buleleng) mengadu ke DPRD karena tidak bisa mencairkan dana tabungan mereka pada LPD setempat ${ }^{5}$, beberapa nasabah LPD Tanggahan Peken menggugat LPD Tanggahan Peken (Bangli) ke Pengadilan Negeri menuntut pengembalian uang mereka setelah LPD tersebut ditutup karena bangkrut ${ }^{6}$, kemudian kejadian yang terbaru ialah tuntutan pengembalian uang nasabah kepada LPD Desa Anturan Buleleng. 7 Beberapa contoh peristiwa hukum tersebut diatas menunjukkan kekhawatiran masyarakat terhadap kepastian hukum terhadap penjamin dana simpanannya. Adanya gejolak dalam masyarakat seperti ini, tentu akan mengurangi kepercayaan para nasabah kepada LPD dikemudian hari, khususnya tentang keamanan dana simpanannya.

Kepastian hukum, menurut C.S.T Kansil dan kawan-kawan dalam kamus istilah hukum (2009), menyatakan dari sudut pandang yuridis ialah pada saat suatu peraturan perundang-undangan dibentuk dan diberlakukankan secara resmi, maka aturan tersebut wajib mengatur sesuatu hal dengan jelas dan logis. Kemudian tentang perlindungan hukum, hasil penelitian Juanda Mamuaja mengenai aspek perlindungan hukum nasabah dalam dunia perbankan, menyimpulkan bahwa terdapat dua metode perlindungan yakni perlindungan yang implisit serta yang eksplisit. Metode perlindungan implisit ialah dengan cara Bank diawasi dan ada pembinaan dari Bank Indonesia (BI) untuk mengantisipasi Bank mengalami kebangkrutan. Pola ini dilakukan dengan cara mengatur dan menegakkan peraturan perundang-undangan yang terkait dengan praktek perbankan. Pola perlindungan yang eksplisit ialah perlindungan dengan membentuk sebuah lembaga penjamin dana simpanan masyarakat. Apabila bank mengarah kepada bank gagal maka lembaga penjamin itu akan bertanggung jawab terhadap dana simpanan masyarakat tersebut. ${ }^{8}$ Salah satu lembaga yang telah dikenal sebagai penjamin dana simpanan para nasabah disebut dengan lembaga penjamin simpanan. Di Indonesia segala hal yang berkaitan dengan penjamin simpanan diatur oleh Undang-Undang Nomor 24 Tahun 2004 Tentang Lembaga Penjamin Simpanan. (selanjutnya disebut dengan UU LPS). Dalam UU LPS itu telah diatur bahwa Penjaminan Simpanan Nasabah, adalah segala upaya dari penjamin yang dalam hal ini dilakukan oleh LPS atas simpanan masyarakat. Dari uraian ini adanya pengaturan tentang pengawasan dan pembinaan dari BI dan adanya

${ }^{4}$ Murniasih, N. N. (2016). Peranan Lembaga Perkreditan Desa Dalam Meningkatkan Perekonomian Masyarakat Bali. Social Studies, 4(2), h. 30-40.

${ }^{5}$ Edy M Yakub (ed). Sepuluh nasabah LPD Gerokgak datangi DPRD Buleleng. Tersedia di URL: https:// bali.antaranews.com/berita/127745/sepuluh-nasabah-lpd-gerokgak-datangi-dprd buleleng. (Diakses: 5 Juni 2020).

6 Agung Samudra. LPD Tanggahan Peken Digugat Nasabahnya. Tersedia di URL: https://balitribune.co.id/content/lpd-tanggahan-peken-digugat-nasabahnya. ( Diakses: 5 Juni 2020).

7 Fakta Pers id, (2020) Ojk harus turun tangan, Lpd anturan dituntut kembalikan uang nasabah. Tersedia di URL: https://faktapers.id/2020/06/ojk-harus-turun-tangan-lpd-anturan-dituntutkembalikan-uang-nasabah/ (Diakses 22 Juni 2020)

8 Mamuaja, J. (2015). Fungsi lembaga penjamin simpanan dalam rangka perlindungan hukum bagi nasabah perbankan di Indonesia. Lex Privatum, 3(1).h.48 
lembaga penjamin simpanan merupakan syarat adanya kepastian hukum bagi simpanan para nasabah LPD di Bali.

Diaturnya LPD dalam dua sistem hukum yang berbeda merupakan sebuah keunikan tersendiri yang menggambarkan beragam budaya hukum masyarakat indonesia. Akan tetapi, pertanyaanya bagaimana dengan aspek kepastian hukum penjamin simpanan dana nasabah LPD ditengah pemberlakuan pluralisme hukum terhadap LPD di Bali? Pertanyaan ini menjadi relevan jika dikaitkan dengan pernyataan Profesor Erman Rajaguguk, yang dinyatakan pada Kongres Internasional yang kelima belas tentang Kajian Terhadap Pluralisme Hukum yang dilaksanakan di Fakultas Hukum Universitas Indonesia, disebutkan bahwa kendala terberat dari penerapan pluralisme hukum di negara Indonesia ialah mewujudkan aspek kepastian hukum. ${ }^{9}$

Penelitian yang berjudul Kebangkrutan LPD Berdasarkan Analisis Berbagai Faktor juga mempertanyakan aspek kepastian hukum tentang penjamin simpanan bagi para nasabah LPD ini dengan menyebut dibutuhkan aturan yang detail, termasuk didalamnya adalah tentang sanksi pidana dan diperlukan semacam Lembaga Penjamin Simpanan (LPS) yang khusus untuk LPD, karena LPD tidak sama dengan perbankan atau lembaga keuangan mikro sehingga tidak masuk dalam LPS. 10

Dengan demikian, dari pemaparan pendahuluan diatas penulis tertarik untuk mengkaji permasalahan perlindungan hukum terhadap dana simpanan ini dalam bentuk karya ilmiah dengan tujuan untuk mengkaji norma - norma dalam dua sistem hukum (pluralisme hukum) tentang kepastian hukum penjamin simpanan terhadap dana simpanan para nasabah LPD dalam pemberlakuan dua model sistem hukum (pluralisme hukum) terhadap LPD di Bali.

\section{Metode Penelitian}

Dari uraian pendahuluan diatas, dalam penulisan karya ini akan digunakan metode penelitian doktrinal (normatif). Adapun mengenai penelitian hukum doktrinal atau normatif ialah penelitian hukum yang dilakukan dengan menggunakan cara dengan mengkaji aturan -aturan hukum yang saat ini berlaku dan mengkaji seperti apa praktiknya dengan menemukan kebenaran yang didasari oleh logika hukum dari sudut normative. ${ }^{11}$ Adapun metode pendekatan perundang-undangan (statute approach) dan metode pendekatan konsep (conceptual approach) akan dipilih sebagai instrumen pendekatan dalam penulisan penelitian ini. Model pendekatan perundangundangan digunakan untuk mengkaji segala peraturan perundang-undangan yang berkaitan dengan LPD di Bali, mulai dari Undang-Undang hingga Peraturan Daerah. Kemudian pendekatan konseptual dipilih untuk mendapatkan argumentasi atau pendapat dalam bentuk doktrin-doktrin dari para ahli yang fokus pada isu hukum ini dengan tujuan untuk mendapatkan penjelasan tentang konsep-konsep hukum yang

9 Hukum Online, Pluralisme harus diakui, tersedia di https://www.hukumonline.com/berita/baca/hol15089/pluralisme-hukumharus-diakui/ (Diakses tanggal 9 Juli 2020)

10 Saputra, K. A. K., Trisnadewi, A. A. E., Anggiriawan, P. B., \& Kawisana, P. G. W. P. (2019). Kebangkrutan Lembaga Perkreditan Desa (Lpd) Berdasarkan Analisis Berbagai Faktor. JIA (Jurnal Ilmiah Akuntansi), 4(1). DOI: http://dx.doi.org/10.23887/jia.v4i1.17250, h.3.

11 Diantha.M.P, Dharmawan.S.N.K, Artha.G. (2018). Metode Penelitian Hukum dan Penulisan Disertasi. Denpasar : Swasta Nulus, h.4 
tidak dijelaskan dalam peraturan perundang-undangan. Selanjutnya permasalahan akan dianalisis menggunakan beberapa bahan hukum yaitu bahan hukum primer dan sekunder. Adapun jenis bahan hukum primer yang akan digunakan meliputi, UU LPS, UU LKM, Perda Desa Adat, Perda LPD, Pergub Provinsi Bali tentang LPD. Berikutnya mengenai bahan hukum sekunder, penulisan ini akan menggunakan literatur-literatur hukum yang relevan sebagai referensi dengan isu hukum yang dipilih diatas. Selain itu, penulisan ini juga menggunakan bahan non-hukum sebagai referensi, seperti data dari media cetak offline maupun online. Bahan-bahan hukum dan non hukum tersebut dikumpulkan dengan melakukan penelusuran literatur di perpustakaan dan internet. Setelah itu hasilnya dicatat menggunakan kartu sebagai alat bantu. Terakhir, setelah bahan-bahan penelitian terkumpul, selanjutnya bahan hukum dan non hukum tersebut diolah dan dianalisis dengan cara kualitatif, kemudian seluruh hasil penelitian ditulis dengan cara deskriptif naratif.

\section{Hasil dan Pembahasan}

\subsection{Pluralisme Hukum dalam Pengaturan LPD di Bali.}

Menurut John Griffiths yang dikutip dari buku Pluralisme Hukum Sebuah Pendekatan Interdisipliner, menyatakan pluralisme hukum ialah adanya kondisi dalam lapangan sosial yang sama diberlakukan dua atau lebih tatanan atau sistem hukum. Dua tatanan atau sistem hukum yang dimaksud menunjuk pada tatanan hukum negara dan kaidah-kaidah hukum rakyat yang pada dasarnya bukan berasal dari negara seperti kaidah adat, agama, kebiasaan, kesepakatan-kesepakatan sosial) disisi yang lainnya. Dikutip dari buku Pluralisme Hukum Sebuah Pendekatan Interdisipliner tersebut ada dua jenis pluralisme hukum yang di utarakan Jhon Griffiths yakni, pluralisme hukum yang sifatnya lemah (weak legal pluralism) dan pluralisme hukum yang sifatnya kuat (strong legal pluralism). Apabila aturan berpusat pada hukum negara, atau hukum negara dipandang sebagai superior (sentralisme menguat), sedangkan tatanan hukum rakyat diposisikan dibawah sistem hukum negara tetapi hukum rakyat tetap diakui, kondisi seperti ini dikatagorikan jenis Pluralisme hukum yang lemah. Sedangkan jika yang terjadi sebaliknya, antara tatanan sistem hukum yang berlaku diposisikan sama didalam kehidupan masyarakat, tidak ada susunan atau hierarki yang memposisikan sistem hukum yang lebih tinggi dari pada sistem hukum yang lain dikatagorikan sebagai pluralisme hukum yang kuat. ${ }^{12}$

Bagi bangsa yang mempunyai banyak ragam budaya, agama, adat dan tradisi, pandangan pluralisme hukum berguna untuk menjelaskan tentang bagaimana cara bekerjanya sistem hukum yang berbeda dalam suatu perkara tertentu. Namun sayangnya masih cukup banyak kalangan sulit menerima kenyataan akan keberadaan sistem hukum lain disamping hukum negara. ${ }^{13}$ Dalam uraian latar belakang diatas telah disebut ada dua sistem hukum yang mengatur operasional LPD di Bali. Bentuk bentuk hukum negara dalam pengaturan LPD ialah Peraturan Daerha Provinsi Bali, kemudian disatu sisi hukum rakyat telah disebut bentuknya ialah hukum adat. Dalam bab ini akan diurai sifat pengaturan LPD di Bali dalam hukum negara dan dalam hukum adat. Selanjutnya akan dianalisis mengenai sifat hubungan atau korelasi "bekerjanya" hukum negara dengan hukum adat.

${ }^{12}$ Loc.cit

${ }^{13}$ Loc.cit 
Adapun hukum adat yang dimaksud dalam Perda Desa Adat tentu ialah hukum adat Bali. Pengertian Hukum adat Bali ialah kumpulan norma atau kaidah yang tertulis atau tidak tertulis yang bentuknya berupa perintah dan larangan serta kebolehan yang digunakan oleh masyarakat Bali sebagai landasan hidup yang berkaitan dengan hubungan antar manusia, manusia dan lingkungan serta tentang relasi manusia dan tuhan yang maha kuasa. ${ }^{14}$ Lazimnya bentuk aturan adat di provinsi Bali ialah berupa awig-awig dan pararem. Dalam pasal 1 angka 29 Perda Desa Adat disebutkan AwigAwig ialah kaidah aturan adat yang dibuat oleh Desa Adat dan/atau Banjar Adat yang berlaku bagi Krama Desa Adat, Krama Tamiu, dan Tamiu. Kemudian dalam pasal 1 angka 30 Perda Desa Adat disebutkan pengertian Pararem adalah aturan atau putusanputusan rapat adat yang berfungsi sebagai pelaksana dari awig-awig atau mengatur hal baru dan/atau menyelesaikan perkara adat atau wicara Adat. Selanjutnya awig-awig dan pararem ini dijalankan oleh Desa Adat melalui Prajuru Adatnya sebagai bentuk kaidah atau pranata hukum Masyarakat hukum Adat di Bali. Adapun analisisnya dilakukan dengan mengkaji pasal- pasal dalam perda LPD dan Perda desa adat, serta kaidah adat Bali (awig-awig dan pararem).

Dari perspektif hukum negara, sejarah keberadaan LPD dalam bentuk organisasi usaha keuangan komunitas adat di Bali sejak awal pendiriannya hingga kini selalu berdasarkan Peraturan Daerah tentang LPD. Pada umumnya Peraturan Daerah tentang LPD memuat pengakuan, perlindungan, pengayoman untuk kemajuan LPD. Adapun dinamika pengaturan/peraturan tentang LPD semenjak baru didirikan ialah sebagai berikut : SK Kep. Daerah Tingkat I Bali No.972 Tahun 1984, tanggal 1 Nopember 1984. Kemudian diganti dengan Perda Tingkat I Bali No.2 Tahun 1988 tentang LPD. Selanjutnya diganti dengan Perda Provinsi Bali No. 8 Tahun 2002 tentang LPD. Berikutnya diubah dengan Perda Provinsi Bali No.3 Tahun 2007 tentang Perubahan Atas Peraturan Daerah Provinsi Bali No.8 Tahun 2002 tentang LPD. Diubah dengan Perda Provinsi Bali No.4 Tahun 2012 tentang Perubahan Kedua Atas Peraturan Daerah Provinsi Bali No.8 Tahun 2002 tentang LPD. Terakhir perubahan ketiga ialah lahirnya Perda LPD.

Secara normatif Perda LPD mengatur tentang status dan penggunaan nama yang diatur dalam Pasal 2 ayat (1) dan (2) yang secara lengkap disebut sebagai berikut: (1) Nama LPD hanya dapat digunakan oleh badan usaha keuangan milik Desa. (2) Setiap orang dilarang menggunakan nama LPD selain sebagaimana dimaksud pada ayat (1). Kemudian Pasal 4 mengatur tentang ijin pendirian LPD ditetapkan dengan Keputusan Gubernur yang kutipannya sebagai berikut : (1) LPD dapat didirikan pada Desa dalam wilayah Kabupaten/Kota. (2) Dalam tiap-tiap Desa hanya didirikan 1 (satu) LPD. Tentang bidang usaha diatur dalam pasal 7 yakni LPD dapat menerima atau mengumpulkan dana dari warga desa adat dalam bentuk dhana sepelan dan dhana sesepelan. Selanjutnya yang paling vital dalam lembaga keuangan penting yaitu tentang modal dengan ketentuan modal LPD dapat didirikan dengan modal awal minimal Rp 50.000.000,00 (lima puluh juta rupiah diatur dalam pasal 9. Untuk menjalankan tugastugas, Perda LPD juga mengatur organisasi LPD terdiri dari Prajuru (terdiri dari Pamucuk, Panyarikan, Patengen) LPD dan Panureksa juga telah diatur. Selain itu, Perda LPD juga mengatur tentang lembaga pemberdayaan LPD sebagai lembaga

${ }^{14}$ Windia Wayan P., Sudantra IK, (2016), Pengantar Hukum Adat Bali, Denpasar, Swasta Nulus Bekerja sama dengan Bali Shanti Pusat Pelayanan Adat dan Budaya Bali LPPM Unud, dan Puslit Hukum Adat LPPM Unud, h. 8. 
berfungsi untuk memberdayakan LPD diatur dalam pasal 13. Pasal 15 menentukan tentang rencana kerja dan anggaran LPD. Mengenai pembinaan dan pengawasan ditentukan dalam pasal 19, yang dilakukan oleh Gubernur, Bupati, Walikota bersama MUDP dan PHDI. Berikutnya yang terkait dengan fokus penelitian ini yakni tentang dana perlindungan, penjaminan dan penyangga ikuiditas diatur dalam pasal 22. Selanjutnya Perda LPD juga mengatur tentang cara bagi keuntungan, mekanisme pembubaran dan tata cara pengurusan harta kekayaan, penerapan sanksi administratif , kemudian tentang ketentuan pidana.

Walaupun telah mengatur sebagian besar tentang pokok-pokok pendirian dan pengelolaan LPD, namun Pasal 12 Perda LPD tetap menentukan bahwa "semua aktifitas LPD dijalankan berdasarkan awig-awig, Pararem Desa dan Peraturan Daerah ini". Tidak ada tafsir autentik mengenai norma ini dalam penjelasan Perda LPD ini. Sehingga sulit memastikan sejauh mana peran awig-awig dan pararem mengatur operasional LPD di Bali, karena dari awal yakni pendirian, permodalan, pemberdayaan dan akhir yaitu tentang pembubaran LPD di Bali telah diatur oleh Perda LPD. Namun jika norma pasal 12 Perda LPD tersebut ditafsir secara gramatikal dan sistematis, susunan atau penempatan awig-awig dan pararem diawal sebelum Perda LPD dalam rumusan pasal 12 Perda LPD ini menunjukan bahwa hukum adat sebagai dasar rujukan pertama dalam operasional LPD di Bali dan menunjukan bahwa Perda LPD sebagai dasar rujukan yang kedua. Adanya ketentuan pasal 12 Perda LPD ini menunjukan bahwa LPD di Bali diatur oleh lebih dari satu sistem hukum yang berbeda yaitu hukum negara berupa Perda dan diatur dalam hukum adat Bali berupa awig-awig dan pararem.

Dalam Perda Desa Adat, terminologi LPD telah diganti dengan istilah Labda Pacingkreman Desa Adat. Dalam Pasal 61 ayat (2) Perda Desa Adat, disebutkan juga bahwa LPD merupakan badan usaha keuangan miik komunitas desa adat yang diakui keberadaannya, dibentuk, diatur, dan dikelola berdasarkan hukum adat. Dengan metode penafsiran gramatikal, tidak sulit menemukan makna yang terkandung dalam norma ini, karena sudah sangat jelas dan tegas rumusannya yaitu LPD di Bali diakui sebagai badan usaha keuangan milik komunitas Adat Bali oleh karena itu atas keberadaanya, pembentukan dan pengelolaannya didasari oleh hukum adat. Kemudian mengenai pengertian tentang hukum adat, Djamanat Samosir (2013), menyebutkan ialah suatu model hukum yang dibangun baik yang bersifat riil maupun idiil berasal dari bangsa Indenesia dengan bahasa suku bangsa Indonesia. Melihat pola pengaturan LPD dalam Perda Desa Adat seperti tersebut diatas, dapat dikatakan tidak ada kewajiban bagi Prajuru untuk menyusun aturan tentang pembentukan dan pengelolaan LPD di Bali dalam awig-awig maupun Pararem di Desa Adatnya. Karena tidak ada satu klausul pasal pun yang memuat ketentuan agar Prajuru Desa Adat menurunkan atau mengimplentasikan Pasal 61 ayat 2 Perda Desa Adat ini ke dalam awig-awig sebagai tanggung jawab moril diakomodirnya LPD dalam Perda Desa Adat. Pengaturan tentang LPD yang tidak ada penjelasan yang terdapat dalam Perda LPD dan Perda Desa Adat seperti ini tentu tidak sejalan dengan asas kejelasan tujuan dalam setiap norma hukum yang diatur dalam Pasal 5 Undang Undang Nomor 12 Tahun 2011 Tentang Pembentukan Peraturan Perundang-Undangan.

Selain diatur dalam Perda, LPD juga diatur dalam awig-awig dan pararem. Untuk mengetahui contoh pengaturan LPD dalam awig-awig atau pararem yang notabene salah satu bentuk hukum adat bali maka, dalam pembahasan ini akan disajikan hasil 
penelitian penulis terhadap beberapa awig-awig dan pararem yang mewakili sembilan (9) Kabupaten dan Kota di Bali. Adapun hasil penelitiannya telah dituangkan dalam tabel sebagai berikut.

Tabel : Hasil Penelitian Terhadap sembilan Awig-Awig dan Pararem.

\begin{tabular}{|c|c|c|c|c|}
\hline No. & Nama Desa Adat & Awig-awig & Pararem & Keterangan \\
\hline 1. & $\begin{array}{l}\text { Desa Adat Banyu Biru, } \\
\text { Negara Jembrana. }\end{array}$ & $\begin{array}{l}\text { Tidak ada } \\
\text { mengatur } \\
\text { tentang lembaga } \\
\text { perkreditan desa. }\end{array}$ & $\begin{array}{l}\text { Tidak ada } \\
\text { pararem } \\
\text { khusus } \\
\text { tentang LPD }\end{array}$ & $\begin{array}{l}\text { Prajuru Desa Adat } \\
\text { Banyu Biru, belum } \\
\text { menurunkan } \\
\text { ketentuan Perda Desa } \\
\text { Adat dan Perda LPD } \\
\text { ke dalam awig-awig } \\
\text { dan pararem. }\end{array}$ \\
\hline 2. & $\begin{array}{l}\text { Desa Adat Belumbang, } \\
\text { Kerambitan,Tabanan }\end{array}$ & $\begin{array}{l}\text { LPD disebut } \\
\text { dalam Palet } 5 \\
\text { indik druwen desa, } \\
\text { Pawos 21, angka } \\
\text { 5, dengan hanya } \\
\text { menyebut } \\
\text { Lembaga } \\
\text { Perkreditan } \\
\text { Desa. (LPD). }{ }^{15}\end{array}$ & $\begin{array}{l}\text { Tidak ada } \\
\text { Pararem yang } \\
\text { mengatur } \\
\text { tentang LPD }\end{array}$ & $\begin{array}{l}\text { Walaupun LPD telah } \\
\text { disebut dalam awig- } \\
\text { awig Desa Adat } \\
\text { Blumbang, namun } \\
\text { ketentuan mengenai } \\
\text { lembaga penjamin } \\
\text { simpanan tidak ditur. }\end{array}$ \\
\hline & $\begin{array}{l}\text { Desa Adat Unggasan, } \\
\text { Kuta Selatan, Badung }\end{array}$ & $\begin{array}{l}\text { LPD tidak ada } \\
\text { disebut dan } \\
\text { diatur dalam } \\
\text { awig-awig Desa } \\
\text { Adat Unggasan. }\end{array}$ & $\begin{array}{l}\text { LPD disebut } \\
\text { dalam Pararem } \\
\text { tersendiri. } \\
\text { Pararem } \\
\text { mengatur } \\
\text { tentang: } \\
\text { lingkup } \\
\text { wilayah LPD, } \\
\text { Modal, badan } \\
\text { pengawas, } \\
\text { badan } \\
\text { pembina, } \\
\text { kewajiban } \\
\text { desa adat, } \\
\text { aturan usaha } \\
\text { simpan } \\
\text { pinjam, } \\
\text { pembagian } \\
\text { keuntungan, } \\
\text { gaji karyawan } \\
\text { dan teknis } \\
\text { rapat. }\end{array}$ & $\begin{array}{l}\text { Walaupun Desa Adat } \\
\text { Unggasan sudah } \\
\text { memiliki Pararem } \\
\text { LPD, namun Pararem } \\
\text { LPD Desa Adat } \\
\text { Unggasan belum } \\
\text { mengatur khusus } \\
\text { tentang penjaminan } \\
\text { simpanan para } \\
\text { nasabah. }\end{array}$ \\
\hline & $\begin{array}{l}\text { Desa Adat Ketewel, } \\
\text { Sukawati, Gianyar }\end{array}$ & $\begin{array}{l}\text { LPD telah } \\
\text { disebut dalam } \\
\text { Palet } 5 \text { Indik }\end{array}$ & $\begin{array}{l}\text { Tidak ada } \\
\text { Pararem } \\
\text { tentang LPD. }\end{array}$ & $\begin{array}{l}\text { Walaupun LPD telah } \\
\text { disebut dalam awig- } \\
\text { awig Desa Adat }\end{array}$ \\
\hline
\end{tabular}

${ }^{15}$ Desa Blumbang, Kerambitan, Tabanan, 2004, Awig-Awig Desa Pakraman Belumbang, h. 24. ${ }^{16}$ Desa Unggasan, Kuta Selatan, Badung, 2006, Pararem Indik LPD Desa Adat Unggasan, h 1. 


\begin{tabular}{|c|c|c|c|}
\hline & $\begin{array}{l}\text { Druwen Desa, } \\
\text { Pawos 27, huruf J } \\
\text { yaitu: LPD lan } \\
\text { Padruwen Desa } \\
\text { Tyosan. }{ }^{7}\end{array}$ & & $\begin{array}{l}\text { Ketewel, namun } \\
\text { ketentuan mengenai } \\
\text { lembaga penjamin } \\
\text { simpanan tidak ditur } \\
\text { lebih lanjut. }\end{array}$ \\
\hline $\begin{array}{l}\text { 5. Desa Adat Bangklet } \\
\text { Bangli }\end{array}$ & $\begin{array}{l}\text { LPD sudah } \\
\text { disebut dalam } \\
\text { Palet } 5 \text { indik } \\
\text { druwen desa, } \\
\text { Pawos } 21 \text {, huruf } \\
\text { h, dengan hanya } \\
\text { menyebut } \\
\text { Lembaga } \\
\text { Perkreditan } \\
\text { Desa. (LPD). }{ }^{18}\end{array}$ & $\begin{array}{l}\text { Tidak ada } \\
\text { pararem LPD }\end{array}$ & $\begin{array}{l}\text { Walaupun LPD telah } \\
\text { disebut dalam awig- } \\
\text { awig Desa Adat } \\
\text { Banklet, namun } \\
\text { ketentuan mengenai } \\
\text { lembaga penjamin } \\
\text { simpanan tidak ditur. }\end{array}$ \\
\hline $\begin{array}{l}\text { 6. Desa Adat Sengkiding, } \\
\text { Klungkung }\end{array}$ & $\begin{array}{l}\text { LPD sudah } \\
\text { Diatur dalam } \\
\text { Sarga 1, Palet } 5 \\
\text { indik druen desa } \\
\text { pawos } 43 \text { angka 5, } \\
\text { dengan hanya } \\
\text { menyebut LPD } \\
\text { saja. }{ }^{19}\end{array}$ & $\begin{array}{l}\text { Tidak ada } \\
\text { pararem LPD. }\end{array}$ & $\begin{array}{l}\text { Walaupun LPD telah } \\
\text { disebut dalam awig- } \\
\text { awig Desa Adat } \\
\text { Sengkiding, namun } \\
\text { ketentuan mengenai } \\
\text { lembaga penjamin } \\
\text { simpanan tidak ditur. }\end{array}$ \\
\hline $\begin{array}{l}\text { 7. Desa Adat Geriyana } \\
\text { Kangin, Selat, } \\
\text { Karangasem }\end{array}$ & $\begin{array}{l}\text { Tidak ada } \\
\text { mengatur } \\
\text { tentang } \\
\text { keberadaan, } \\
\text { pembentukan } \\
\text { dan pengelolaan } \\
\text { LPD. }\end{array}$ & $\begin{array}{l}\text { Tidak ada } \\
\text { Pararem } \\
\text { tentang LPD }\end{array}$ & $\begin{array}{l}\text { Prajuru Desa Adat } \\
\text { Geriyana Kangin } \\
\text { belum menurunkan } \\
\text { ketentuan Perda Desa } \\
\text { Adat dan Perda LPD } \\
\text { ke dalam awig-awig } \\
\text { dan pararem. }\end{array}$ \\
\hline $\begin{array}{l}\text { 8. Desa Adat Sangsit Dauh } \\
\text { Yeh Buleleng }\end{array}$ & $\begin{array}{l}\text { Tidak ada } \\
\text { mengatur } \\
\text { tentang } \\
\text { keberadaan, } \\
\text { pembentukan } \\
\text { dan pengelolaan } \\
\text { LPD. }\end{array}$ & $\begin{array}{l}\text { Tidak ada } \\
\text { Pararem } \\
\text { tentang LPD. }\end{array}$ & $\begin{array}{l}\text { Prajuru Desa Adat } \\
\text { Sangsit Dauh Yeh } \\
\text { Buleleng belum } \\
\text { menurunkan } \\
\text { ketentuan Perda Desa } \\
\text { Adat dan Perda LPD } \\
\text { ke dalam awig-awig } \\
\text { dan pararem. }\end{array}$ \\
\hline $\begin{array}{l}\text { 9. Desa Adat Kesiman, } \\
\text { Denpasar Timur, Kota } \\
\text { Denpasar }\end{array}$ & $\begin{array}{l}\text { LPD disebut } \\
\text { dalam Palet } 6 \\
\text { indik Druen Desa, } \\
\text { Pawos 19, angka } \\
\text { VI. Ha dengan } \\
\text { sebutan LPD : } \\
\text { Lembaga } \\
\text { Perkreditan Desa } \\
\text { (Adat) saha } \\
\text { kantor abungkul }\end{array}$ & $\begin{array}{l}\text { Belum ada } \\
\text { Pararem } \\
\text { tentang LPD }\end{array}$ & $\begin{array}{l}\text { Walaupun LPD telah } \\
\text { disebut dalam awig- } \\
\text { awig Desa Adat } \\
\text { Kesiman, namun } \\
\text { ketentuan mengenai } \\
\text { lembaga penjamin } \\
\text { simpanan tidak ditur. }\end{array}$ \\
\hline
\end{tabular}

${ }^{17}$ Desa Ketewel, Sukawati, Gianyar, 1995, Awig-Awig Desa Adat Ketewel, h. 10.

${ }^{18}$ Krama Desa Adat Bangklet, 1996, Awig-Awig Desa Adat Bangklet, h. 9.

${ }^{19}$ Krama Desa Adat Sengkiding, 1987, Awig-Awig Desa Adat Sengkiding, Banjarangkan, Klungkung, h. 45 


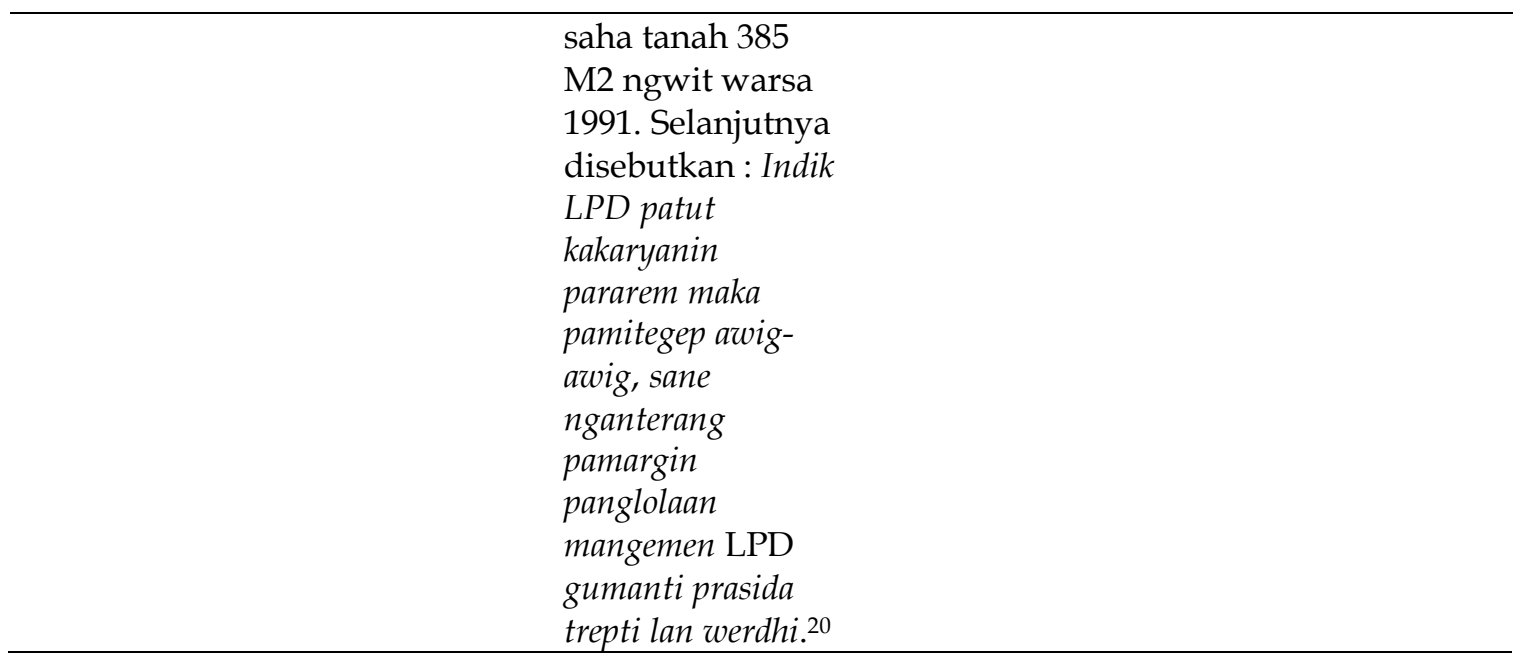

Sumber : Sembilan Awig-awig dan Pararem perwakilan Kabupaten/Kota di Bali yang diolah penulis.

Beranjak dari kajian terhadap norma-norma dalam Perda LPD dan beberapa awig-awig dan pararem diatas, nampaknya sebagian besar tentang operasional LPD telah diatur dalam Perda LPD, mulai dari hal pendirian LPD, pemberdayaan LPD dan pembubaran LPD di Bali telah diatur. Kemudian mengenai pengaturan operasional LPD dalam hukum adat Bali, dari sembilan contoh awig-awig dan satu pararem yang diteliti, ditemukan hanya enam Desa Adat yang menyebut LPD sebagai druwen desa (milik desa adat). Tiga Desa Adat malahan tidak ada menyebut LPD sama sekali dalam awig awignya. Selanjutnya tidak ada penjabaran lainnya lagi tentang operasional LPD di Bali. Sehingga dalam bab ini dapat disimpulkan sifat hubungan atau "bekerjanya" dua sistem hukum (pluralisme hukum) yakni hukum negara melalui Perda LPD dan hukum adat melalui awig-awig serta pararem ini menunjukan hukum negara mengatur dengan porsi yang sangat dominan dari pada hukum adat Bali.

\subsection{Kepastian Hukum Mengenai Penjamin Simpanan Nasabah LPD di Bali.}

Diaturnya operasional atau pengelolaan LPD di Bali dengan dua sistem hukum sebagaimana telah terurai diatas seyogyanya membuahkan perlindungan hukum yang maksimal kepada para nasabah, sehingga dari itu diharapkan adanya kepastian hukum atas penjamin simpanan dana nasabah LPD di Bali. Kemudian pertanyaannya apakah model pengaturan dengan dua sistem hukum (pluralisme hukum) tersebut telah menjamin kepastian hukum bagi simpanan para nasabah LPD di Bali?

Melihat pola operasional yang diterapkan oleh LPD di Bali, nampak bahwa LPD di Bali menjalankan kegiatan perbankan seperti praktek Bank umum yang ada di Indonesia. Karena dalam penyelengaraan LPD memberlakukan system manajemen keuangan modern, dalam aktifitasnya mendekati pada pola manajemen perbankan. ${ }^{21}$ LPD di Bali dapat disebut mempunyai fungsi sebagai penyambung (intermediary) antara masyarakat yang memiliki dana lebih dan bagian masyarakat yang dalam

${ }^{20}$ Desa Adat Kesiman, 2010, Awig-Awig Desa Pakraman Kesiman, h.16.

${ }^{21}$ Nurjaya I Nyoman, et. al, 2011, Landasan Teoritik Pengaturan LPD (Sebagai Lembaga Keuangan Komunitas Masyarakat Hukum Adat Bali), Udayana University Press, Denpasar. $h$. 37. 
kondisi kekurangan dana. Secara substantif LPD di Bali melaksanakan kegiatan perbankan, dengan demikian risiko- resiko yang dijumpai oleh lembaga - lembag perbankan akan ditemui juga oleh LPD, oleh karena itu menjadi keharusan dalam pengaturannya menerapkan prinsip-prinsip perbankan.22

Sebagai salah satu bentuk usaha yang menarik dana segar dari masyarakat, tentu LPD harus selalu berusaha untuk berinovasi dalam memberikan layanan kepada masyarakat. Sudah banyak predikat positif yang dilekatkan pada LPD di Bali saat ini, oleh karena itu menjaga kepercayaan masyarakat tersebut merupakan sebuah keniscayaan bagi Prajuru Desa Adat dan Petugas LPD di Bali. LPD merupakan salah satu unit lembaga penjaga stabilitas keuangan di Bali, kepercayaan masyarakat hanya dapat diraih dengan maksimal jika ada kepastian hukum dalam aturan tentang keamanan dana simpanan para nasabah. Terlebih saat ini Pasal 39 ayat (3) UU LKM telah menyebutkan bahwa LPD tidak tunduk pada UU LKM. Pada saat UU LKM diberlakukan dahulu, ketentuan pasal 39 ayat (3) ini sempat membuat kondisi kekosongan hukum tentang pengaturan LPD di Bali, karena substansi norma dalam UU LKM saat itu belum ditindaklanjuti oleh pemerintah Provinsi Bali dalam bentuk revisi Perda LPD dengan tujuan aturan dan pengelolaan LPD disesuaikan dengan pakem-pakem hukum adat. ${ }^{23}$ Berkaitan dengan semua hal itu, maka saat ini peran pakem atau kaidah - kaidah dalam awig-awig, pararem serta norma-norma aturan dalam Perda LPD sangat penting untuk menjamin aspek kepastian hukum keamanan dana simpanan para nasabah LPD di Bali.

Pengertian kepastian hukum dalam kamus istilah hukum karangan C.S.T Kansil menyebutkan dari sudut pandang yuridis kepastian hukum ialah saat suatu peraturan perundang-undangan dibentuk dan diundangkan, harus dipastikan aturan tersebut telah mengatur suatu hal dengan syarat jelas dan logis. Arti kata jelas ialah suatu hal yang tidak mengandung unsur keragu-raguan atau tidak mengundang banyak tafsir dan logis. Selain itu, jelas dalam arti aturan tersebut merupakan suatu sistem norma yang tidak beertentangan atar norma yang satu dengan norma lain. Jadi kepastian hukum merupakan sebuah pemberlakuan aturan hukum yang jelas, tetap, konsisten serta akibatnya nanti tidak diintervensi kepentingan - kepentingan yang bersifat subjektif. Oleh karena itu kepastian hukum dan keadilan menurut hukum dan tidak hanya sekedar tuntutan moral, melainkan secara riil merupakan sebuah rangkaian norma yang mencerminkan hukum.

Adanya sebuah lembaga sebagai penjamin simpanan dana ialah merupakan salah satu syarat adanya perlindungan hukum bagi simpanan para nasabah. Agar penjamin simpanan itu mempunyai kepastian hukum maka seyogyanya keberadaan lembaga penjamin simpanan tersebut diatur kedalam peraturan perundang-undangan yang berlaku. Sebagai sebuah upaya meningkatkan peran LPD, Gubernur Bali telah membentuk sebuah lembaga pemberdayaan yang dikenal dengan istilah Lembaga

${ }^{22}$ Tanaya, P. E. (2019). Konstruksi Pengaturan Prinsip Mengenal Nasabah dalam Lembaga Perkreditan Desa di Bali. Kertha Wicaksana: Sarana Komunikasi Dosen dan Mahasiswa, 13(2), h. 102-108.

${ }^{23} J a y a n t h i$ Devi, N. M., Wairocana, I. G. I. N., \& Wiryawan, I. W. (2018). Status dan Kedudukan Lembaga Perkreditan Desa (Lpd) Terkait Pengikatan Jaminan dengan Berlakunya Undangundang Nomor 1 Tahun 2013 Tentang Lembaga Keuangan Mikro. Acta Comitas, 2, 201-212. 
Pemberdayaan Lembaga Perkreditan Desa yang kemudian akan disebut dengan LP LPD dengan fungsi melaksanakan pemberdayaan bagi LPD yang terdaftar. Kemudian, bagaimana dengan peran Lembaga Pemberdayaan LPD (LP LPD) yang konon bertugas menyelenggarakan Skim Dana Penjaminan Simpanan para nasabah LPD yang diatur didalam ketentuan Perda LPD?.

Ketentuan pasal 22 ayat (2) Perda LPD menyebutkan bahwa LPLPD (lembaga pemberdayaan LPD) menjalankankan Skim Dana Penjaminan Simpanan nasabah LPD ditetapkan untuk kepentingan penyimpan. Kemudian dilanjutkan pada bagian penjelasannya disebutkan yang dimaksud dengan Skim Dana Penjaminan Simpanan nasabah adalah dana yang dibentuk secara bersama-sama oleh LPD yang dapat digunakan untuk menjamin simpanan nasabah LPD peserta penjaminan. Sistem kerja DPS-LPD Bali bersifat dari, oleh dan untuk kepentingan LPD peserta DPS-LPD Bali. Pengaturan dalam pasal 22 ayat (2) ini bermakna bahwa LPLPD memfasilitasi LPD yang terdaftar untuk menghimpun Dana Penjaminan Simpanan nasabah LPD. Selanjutnya dalam pasal 22 ayat (1),(3),(4),(5) ini tidak ada lagi menyebutkan bahwa LPLPD, merupakan lembaga penjamin simpanan para nasabah LPD di Bali.

Sebagai turunannya, pasal 58 Peraturan Gubernur Bali Nomor 44 tahun 2017 tentang Peraturan Pelaksanaan Perda LPD ( selanjutnya disebut Pergub LPD), menyebutkan tugas LPLPD ialah sebagai pembinaan teknis, pemeriksaan/audit, pelatihan , mengelola dana perlindungan LPD, mengelola dana penjaminan simpanan LPD, mengelola dana penyangga likuiditas LPD, dan penanganan masalah LPD. Dari ketentuan pasal 58 Pergub LPD khususnya huruf (e), bermakna menegaskan kembali bahwa tugas LPLPD salah satunya ialah mengelola dana simpanan dari para nasabah LPD di Bali.

Berkaitan dengan hal itu, dalam Lampiran IX huruf A Pergub Bali tentang LPD, menyebutkan bahwa Kepala LPLPD Provinsi mempunyai fungsi dan tugas sebagai berikut yaitu memimpin kemudian merencanakan dan mengatur serta membina, mengkoordinasikan, memastikan dan mengendalikan berjalannya tugas pokok baik tugas sekretariatan dan tugas Pemberdayaan LPD yang yakni: pembinaan teknis, pemeriksaan atau audit, pelatihan sumber daya manusia LPD, kerjasama dengan pihak lain. Dilanjutkan dalam Lampiran IX D. 2, disebutkan dalam bagian Penjaminan Simpanan Nasabah LPD mempunyai tugas untuk membuat rencana, membuat aturan , memberi pembinaan, menjalankan dan mengontrol sistem pengelolaan uang nasabah LPD dan memberi jaminan terhadap kredit LPD sesuai dengan aturan yang berlaku. Kondisi pengaturan dalam Lampiran Pergub Bali tentang LPD yang notabene pengaturan paling akhir, menunjukan bahwa LPLPD mempunyai fungsi untuk memberdayakan LPD di Bali dalam bidang- bidang tertentu yang salah satunya ialah dalam bidang penjaminan simpanan nasabah.

Dari uraian penelusuran perihal tentang penjamin simpanan dan fungsi LPLPD mulai dari Perda LPD, Pergub Bali tentang LPD hingga sampai pada Lampiran Pergub Bali tentang LPD yang notabene sebagai pengaturan tingkat akhir dalam setiap Peraturan Daerah Provinsi, ditemukan bahwa LPLPD merupakan sebuah lembaga pemberdayaan bagi LPD di Bali untuk memberikan jaminan terhadap simpanan para nasabah LPD di Bali, bukan berfungsi sebagai sebuah lembaga penjamin simpanan dana para nasabah LPD di Bali. 
Kemudian, bagaimana dengan kepastian hukum dalam hukum adat (awig-awig dan pararem)?. Didasari oleh hasil kajian terhadap sembilan awig-awig yang diteliti, ditemukan enam awig-awig menyebutkan bahwa LPD diakui sebagai salah satu kekayaan Desa Adat (druwen desa). Akan tetapi pengakuannya hanya menyebut dengan sangat singkat. Tidak ditemukan lagi penjabaran tentang LPD sebagai milik Desa Adat dalam bentuk pengaturan pembentukan dan pengelolaan, apalagi klausul tentang penjamin simpanan. Pengaturan yang singkat dan kadang tidak diatur merupakan sebuah fenomena nyata dalam hukum adat Bali. Kemudian khusus untuk Desa Adat Unggasan, selain telah disebut dalam awig-awig, mereka juga telah menjabarkan perihal pengelolaan LPD dalam aturan pelaksanaan dalam bentuk pararem. Walaupun begitu, keseluruhan kaidah pararemnya belum ada yang mengatur tentang penjamin simpanan terhadap dana nasabah jika sewaktu-waktu LPD di Bali bangkrut. Kondisi pengaturan seperti ini, tentu belum dapat memberikan kepastian hukum terhadap simpanan para nasabah LPD di Bali.

Penyebutan LPD dalam awig-awig dan pararem yang sangat singkat ini tentu tidak dapat disalahkan. Karena pengaturan LPD di Bali dalam Perda Desa Adat dan Perda LPD tidak jelas memberikan batasan tentang bagian mana dari operasional LPD dapat diatur oleh awig-awig dan pararem. Alih-alih mengatur penjabaran tentang pengelolaan LPD sebagai bentuk padruwen desa itu dengan detail hingga menyebut sebuah lembaga khusus penjamin simpanan. Malahan ada awig -awig Desa Adat yang hanya sekedar menyebut gabungan tiga huruf L-P-D saja, tanpa dilengkapi dengan kepanjangannya yaitu Lembaga Perkreditan Desa. Kondisi pengaturan dalam awigawig dan pararem seperti ini nyambung dengan temuan pada pembahasan pertama diatas, bahwa karena dalam Perda LPD dan Perda Desa Adat tidak memuat tentang kewajiban bagi Prajuru Desa Adat untuk menurunkan ketentuan hukum negara dalam awig-awig dan pararem. Sehingga dengan demikian, melihat kondisi pengaturan LPD dalam awig-awig dan pararem tentu sulit memenuhi unsur dari kepastian hukum yang disebut diatas, yakni sebuah aturan hukum dibuat serta diundangkan mengandung kepastian hukum jika telah mengatur secara jelas dan logis.

Sisanya, ada tiga Desa Adat yakni Desa Adat Banyu Biru, Negara Jembrana, Desa Adat Geriyana Kangin, Selat, Karangasem, Desa Adat Sangsit Dauh Yeh Buleleng tidak ada menyebut dan mengatur LPD didalam awig-awignya, padahal ketiga Desa Adat ini memiliki LPD di wilayahnya. Untuk saat ini, ditengah tuntutan masyarakat akan sebuah keamanan dalam transaksi keuangan, maka fakta pengaturan LPD yang sangat singkat seperti halnya dalam enam awig-awig Desa Adat diatas tentu tidak dapat menjamin aspek kepastian hukum terhadap dana simpanan para nasabah LPD.

Berdasarkan hasil kajian terhadap Perda LPD dan terhadap sembilan contoh awig-awig dan pararem yang diambil dari setiap Kabupaten dan Kota di Bali, tidak ada ditemukan pengaturan tentang penjamin simpanan bagi dana simpanan para nasabah LPD di Bali sebagai syarat perlindungan hukum bagi nasabah. Oleh karena itu pengaturan LPD di Bali dengan dua model sistem hukum yakni hukum negara berupa Perda tentang LPD dan berdasarkan hukum adat berupa awig-awig dan pararemnya tidak menjamin kepastian hukum bagi dana simpanan para nasabah LPD di Bali. 


\section{Kesimpulan}

Didasari oleh uraian pembahasan sebagaimana tersebut diatas dapat disimpulkan hal hal penting sebagai berikut yakni : terdapat dua sistem hukum yang mengatur keberadaan LPD di Bali yaitu hukum negara dan hukum adat Bali. Hukum negara berupa Perda LPD, Perda Desa Adat, dan hukum adat Bali berupa awig-awig dan pararem. Kondisi pengaturan yang lebih dari satu tatanan sistem hukum, dalam studi ilmu hukum dikenal dengan istilah pluralisme hukum. Relasi "bekerjanya" hukum negara dan hukum adat Bali dalam pengaturan LPD di Bali, menunjukan bahwa peran hukum negara dalam hal ini Perda LPD lebih dominan daripada hukum adat dalam pengaturan LPD di Bali. Kemudian pada pokok bahasan kedua, berdasarkan hasil kajian terhadap Perda LPD dan terhadap sembilan contoh awig-awig dan pararem yang diambil dari setiap Kabupaten dan Kota di Bali, tidak ada ditemukan pengaturan tentang penjamin simpanan bagi dana simpanan para nasabah LPD di Bali sebagai syarat perlindungan hukum bagi nasabah. Oleh karena itu pengaturan LPD di Bali dengan dua model sistem hukum yakni hukum negara berupa Perda tentang LPD dan berdasarkan hukum adat berupa awig-awig dan pararemnya tidak menjamin kepastian hukum bagi dana simpanan para nasabah.

\section{Daftar Pustaka}

Buku

Diantha.M.P, Dharmawan.S.N.K, Artha.G. (2018). Metode Penelitian Hukum dan Penulisan Disertasi. Denpasar : Swasta Nulus.

Nurjaya, I Nyoman, et. al, 2011, Landasan Teoritik Pengaturan LPD (Sebagai LembagaKeuangan Komunitas Masyarakat Hukum Adat Bali), Denpasar, Udayana University Press.

Windia, Wayan. P dan Sudantra, I Ketut, (2016), Pengantar Hukum Adat Bali, Denpasar, Swasta Nulus Bekerja sama dengan Bali Shanti Pusat Pelayanan Adat dan Budaya Bali LPPM Unud, dan Puslit Hukum Adat LPPM Unud.

\section{Jurnal}

Dewi, L. P. (2019). Implementasi Peraturan Presiden Nomor 13 Tahun 2018 dalam Pendirian Perseroan Terbatas. Acta Comitas: Jurnal Hukum Kenotariatan, 4(1).

Arifin, J. (2010). Perlindungan hukum nasabah lembaga keuangan mikro syari'ah: studi terhadap nasabah BMT di Kota Semarang. Walisongo Press.

Mamuaja, J. (2015). Fungsi lembaga penjamin simpanan dalam rangka perlindungan hukum bagi nasabah perbankan di Indonesia. Lex Privatum, 3(1).

Murniasih, N. N. (2016). Peranan Lembaga Perkreditan Desa Dalam Meningkatkan Perekonomian Masyarakat Bali. Social Studies, 4(2), 30-40.

Pramana, I. M. I. D., \& Lemes, I. N. (2019). Akibat Hukum Pemberian Kredit Kepada Krama Desa Lain Pada Lembaga Perkreditan Desa Pakraman Anturan, Kecamatan Buleleng, Kabupaten Buleleng. Kertha Widya, 5(1).

Pramana, K. Y., Parwata, A. G. O., \& Dewi, A. I. A. A. (2014). Eksistensi otonomi desa pakraman pada masyarakat adat di Bali. Skripsi tidak dipublikasikan). Fakultas Hukum Universitas Udayana, Bali.

Putra, A. K. Y., \& Sarjana, I. M. Keberadaan Lembaga Perkreditan Desa Di Bali Dalam Perspektif Undang-Undang Nomor 1 Tahun 2013 Tentang Lembaga Keuangan Mikro. Kertha Semaya: Journal Ilmu Hukum, 6(6), 1-13. 
Saputra, K. A. K., Trisnadewi, A. A. E., Anggiriawan, P. B., \& Kawisana, P. G. W. P. (2019). Kebangkrutan Lembaga Perkreditan Desa (Lpd) Berdasarkan Analisis Berbagai Faktor. JIA (Jurnal Ilmiah Akuntansi), 4(1).

Tanaya, P. E. (2019). Konstruksi Pengaturan Prinsip Mengenal Nasabah dalam Lembaga Perkreditan Desa di Bali. Kertha Wicaksana: Sarana Komunikasi Dosen dan Mahasiswa, 13(2).

Yasa, P. H., Rudy, D. G., \& Kusuma, A. G. A. D. Perlindungan Hukum Terhadap Dana Nasabah Yang Disimpan Pada Lembaga Perkreditan Desa (LPD). Kertha Semaya: Journal Ilmu Hukum.

\section{Peraturan-Perundang-Undangan}

Undang Undang Republik Indonesia Nomor 24 Tahun 2004 Tentang Lembaga Penjamin Simpanan (Lembaran Negara Republik Indonesia Tahun 2004 Nomor 96).

Undang-Undang Nomor 1 Tahun 2013 Tentang Lembaga Keuangan Mikro (LembarNegara Republik Indonesia Tahun 2013 Nomor 12).

Peraturan Daerah Provinsi Bali Nomor 3 Tahun 2017 Tentang Lembaga Perkreditan Desa (Lembaran Daerah Provinsi Bali Nomor 3 Tahun 2017). (No Reg Peraturan Daerah Provinsi Bali :3/72/2017).

Peraturan Daerah Provinsi Bali Nomor 4 Tahun 2019 Tentang Desa Adat Di Bali.(Lembaran Daerah Provinsi Bali Tahun 2019 Nomor 4) (No Reg Peraturan Daerah Provinsi Bali : 4-131/2019).

Peraturan Gubernur Bali Nomor 44 Tahun 2017 Tentang Peraturan Pelaksanaan PerdaProvinsi Bali Nomor 3 Tahun 2017 Tentang Lembaga Perkreditan Desa (Lembar Daerah Provinsi Bali Tahun 2017 Nomor 44)

Desa Blumbang, Kerambitan, Tabanan, 2004, Awig-Awig Desa Pakraman Belumbang.

Desa Unggasan, Kuta Selatan, Badung, 2006, Pararem Indik LPD Desa Adat Unggasan

Desa Ketewel, Sukawati, Gianyar, 1995, Awig-Awig Desa Adat Ketewel.

Desa Adat Kesiman, 2010, Awig-Awig Desa Pakraman Kesiman

Krama Desa Adat Bangklet, 1996, Awig-Awig Desa Adat Bangklet.

Krama Desa Adat Sengkiding, 1987, Awig-Awig Desa Adat Sengkiding, Banjarangkan, Klungkung.

Website

Agung Samudra. LPD Tanggahan Peken Digugat Nasabahnya. Tersedia di URL: https://balitribune.co.id/content/lpd-tanggahan-peken-digugat-nasabahnya. Diakses: 5 Juni 2020.

Edy M Yakub (ed). Sepuluh nasabah LPD Gerokgak datangi DPRD Buleleng. Tersedia di URL: https://bali.antaranews.com/berita/127745/sepuluh-nasabah-lpdgerokgak-datangi-dprd-buleleng. Diakses: 5 Juni 2020.

Fakta Pers id, (2020) Ojk harus turun tangan, Lpd anturan dituntut kembalikan uang nasabah. Tersedia di URL: https://faktapers.id/2020/06/ojk-harus-turun-tangan-lpdanturan-dituntut-kembalikan-uang-nasabah/. (Diakses 22 Juli 2020) 